\title{
Application of Response Surface Methodology for Optimizing Arginine Deiminase Production Medium for Enterococcus faecium sp. GR7
}

\author{
Baljinder Kaur and Rajinder Kaur \\ Department of Biotechnology, Punjabi University, Patiala 147002, Punjab, India \\ Correspondence should be addressed to Baljinder Kaur; baljinderbt@hotmail.com
}

Received 29 August 2013; Accepted 23 September 2013

Academic Editors: J. E. Lee and P. Lozano

Copyright (c) 2013 B. Kaur and R. Kaur. This is an open access article distributed under the Creative Commons Attribution License, which permits unrestricted use, distribution, and reproduction in any medium, provided the original work is properly cited.

Arginine metabolism in Enterococcus faecium sp. GR7 was enhanced via arginine deiminase pathway. Process parameters including fermentation media and environmental conditions were optimized using independent experiments and response surface methodology (central composite design). Fermentation media (EAPM) were optimized using independent experiments which resulted in 4-fold increase in arginine deiminase specific activity as compared to basal medium. To further enhance arginine deiminase activity in E. faecium sp. GR7 and biomass production including a five-level central composite design (CCD) was employed to study the interactive effect of three-process variables. Response surface methodology suggested a quadratic model which was further validated experimentally where it showed approximately 15 -fold increase in arginine metabolism (in terms of arginine deiminase specific activity) over basal medium. By solving the regression equation and analyzing the response surface cartons, optimal concentrations of the media components $(\mathrm{g} / \mathrm{L})$ were determined as arginine 20.0; tryptone 15.0; lactose 10.0; $\mathrm{K}_{2} \mathrm{HPO}_{4} 3.0 ; \mathrm{NaCl} 1.0, \mathrm{MnSO}_{4} 0.6 \mathrm{mM}$; Tween 80 1\%; $\mathrm{pH} 6.0$ for achieving specific arginine deiminase activity of $4.6 \mathrm{IU} / \mathrm{mG}$ with concomitant biomass production of $12.1 \mathrm{mg} / \mathrm{L}$. The model is significant as the coefficient of determination $\left(R^{2}\right)$ was 0.87 to 0.90 for all responses. Enhanced arginine deiminase yield from E. faecium, a GRAS lactic acid bacterial strain, is desirable to explore in vitro therapeutic potential of the arginine metabolizing E. faecium sp. GR7.

\section{Introduction}

L-arginine is classified as conditionally essential amino acid for protein synthesis that is metabolized through citrulline, ornithine, creatine, proline, and polyamines in human body $[1,2]$. It is used by a number of microorganisms to generate ATP fermentatively via arginine deiminase (ADI) pathway which is also known as arginine dihydrolase (ADH) pathway [3]. Arginine is metabolized by three successive enzymatic reactions (Figure 1), involving arginine deiminase (ADI; EC 3.5.3.6) to citrulline and ammonia, ornithine transcarbamylase (EC 2.1.3.3) to ornithine and carbamoyl phosphate and finally to ATP by carbamate kinase (EC 2.7.2.2) [4]. ADI activity is previously reported in many lactic acid bacteria including Enterococcus faecalis, Lactobacillus sp., Lactococcus, Leuconostoc, Oenococcus, Streptococcus, and Weissella [3, 510]. In general, arginine induces expression of ADI pathway enzymes, and some carbohydrates such as glucose and galactose are known to control their synthesis by catabolite repression [9].

The present study was aimed to screen and optimize media components that increase ADI activity of Enterococcus sp. RSM, formerly known as Box-Wilson methodology, is the most widely used statistical technique to evaluate relationship between a set of controllable experimental factors and observed results [11]. RSM is capable to find optimum set of experimental factors that produce maximum or minimum value of response and represent the direct and interactive effect of process variables through two-dimensional and three-dimensional graphs. Keeping in view, the great commercial application of ADI as a therapeutic agent; an attempt was made to optimize the composition of the ADI production media for E. faecium sp. GR7 which was carried out in two steps. Independent experiments for the selection of most 


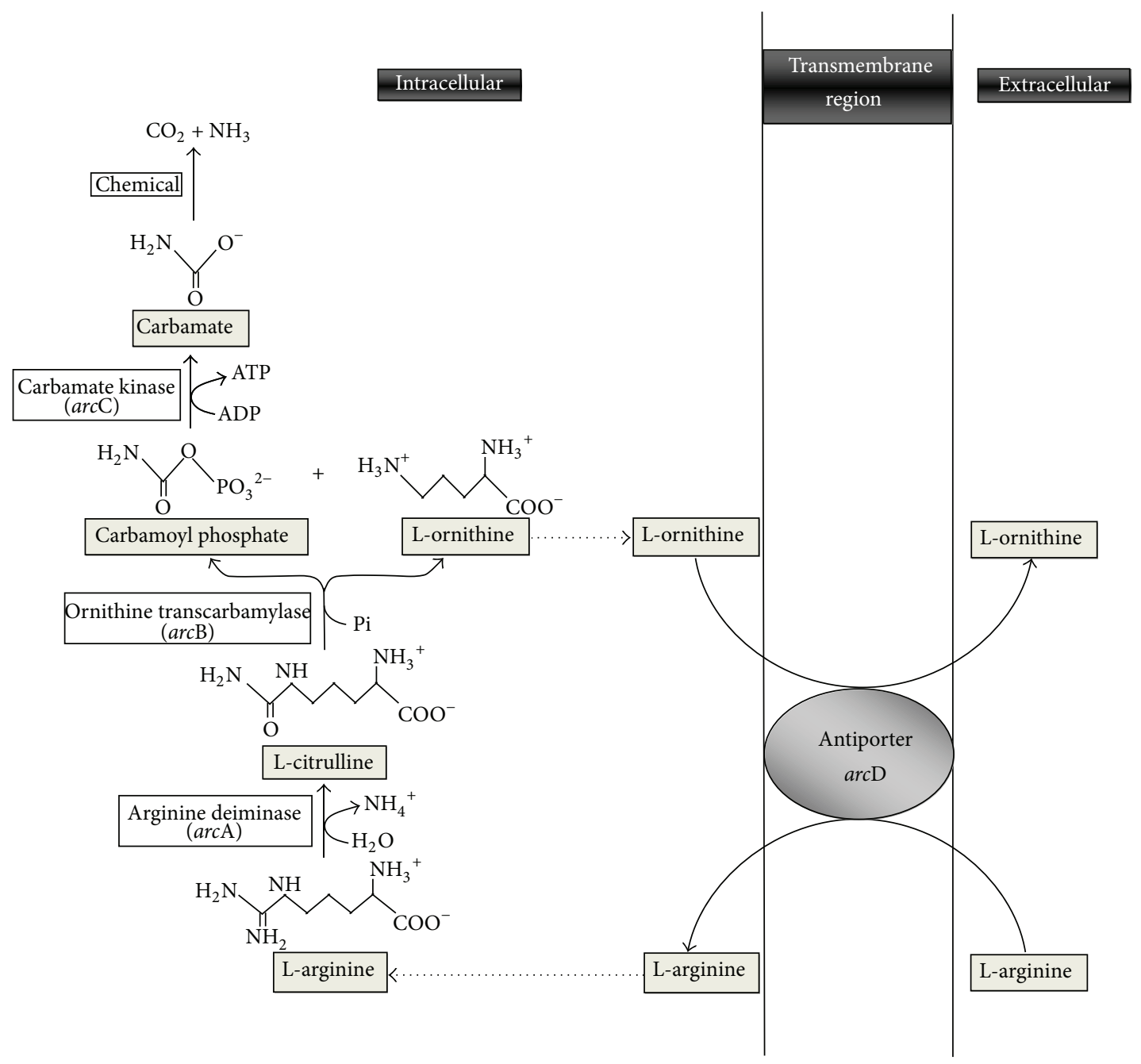

FIgURE 1: Arginine catabolism in E. faecium.

influential process parameters including fermentation media and environmental conditions were performed followed by application of CCD design for final optimization of media components to enhance ADI activity and biomass production using influential process variables.

\section{Materials and Methods}

2.1. Bacterial Strain and Culture Medium Used. E. faecium sp. GR7 used in the study was cultured in MAM medium $(\mathrm{g} / \mathrm{L})$ consisting of tryptone 10.0; glucose 5.0; yeast extract 5.0; arginine 3.0; $\mathrm{KH}_{2} \mathrm{PO}_{4} 0.5 ; \mathrm{MgSO}_{4} 0.2 ; \mathrm{MnSO}_{4} 0.05$; Tween $801.0 \mathrm{~mL} / \mathrm{L}$; Agar 2.0; pH 6.0 [12]. Optical density of the inoculums was adjusted to 1.0 , and $1 \% \mathrm{v} / \mathrm{v}$ culture was used in each experiment. Cultures were incubated at $37^{\circ} \mathrm{C}$ for $24 \mathrm{~h}$.

2.2. Enzyme Assay. To determine enzyme activity, $24 \mathrm{~h}$-old cultures were centrifuged at 8,000 rpm for $10 \mathrm{~min}$. Cell free supernatant (CFS) was assessed for extracellular protein and enzyme activity. For assaying intracellular ADI activity, cell pellet was resuspended in lysis buffer. Total protein was estimated by measuring absorption at $280 \mathrm{~nm}$ using standard curve of BSA. ADI activity was assayed using standard method of De Angelis et al. [12]. Assay mixture consisted of $150 \mu \mathrm{L}$ of $50 \mathrm{mM}$ arginine, $2.3 \mathrm{~mL}$ of $50 \mathrm{mM}$ acetate buffer ( $\mathrm{pH} 5.5$ ), $50 \mu \mathrm{L}$ of cell wall or cytoplasm preparation, and $3.6 \mu \mathrm{L}$ of sodium azide $(0.05 \% \mathrm{w} / \mathrm{v})$. Controls without substrate and without enzyme were included. After incubation at $37^{\circ} \mathrm{C}$ for $1 \mathrm{~h}$, the reaction was stopped by adding $0.5 \mathrm{~mL}$ solution of $2 \mathrm{~N} \mathrm{HCl}$, and precipitated protein was removed by centrifugation. Citrulline content after enzyme assay in CFS was determined by Archibald's method [13]. One milliliter of the supernatant was added to $1.5 \mathrm{~mL}$ of an acid mixture of $\mathrm{H}_{3} \mathrm{PO}_{4}-\mathrm{H}_{2} \mathrm{SO}_{4}(3 / 1 \mathrm{v} / \mathrm{v})$ and $250 \mu \mathrm{L}$ of diacetyl monoxime (1.5\% 2, 3 butanedione monoxime) in $10 \%(\mathrm{v} / \mathrm{v})$ methanol, mixed and boiled in the dark for $30 \mathrm{~min}$. After cooling for $10 \mathrm{~min}$, absorbance was measured at $460 \mathrm{~nm}$ and one enzyme unit was calculated as the amount of enzyme required to catalyze formation of $1 \mu \mathrm{mol}$ citrulline per min. Finally, specific activity was calculated as international enzyme units present per $\mathrm{mg}(\mathrm{IU} / \mathrm{mG})$ of protein.

2.3. Selection of Basal Medium for ADI Production. Six culture media including MAM [12]; MRS [14]; TGYE [15]; 
(modified) MRS broth [12]; Enterococcus confirmatory broth [16]; and M9 Minimal salt media [17] each supplemented with arginine $(15 \mathrm{mM})$ were selected to investigate production of ADI in E. faecium sp. GR7. Inoculums were subcultured twice in MAM broth at $37^{\circ} \mathrm{C}$ for $24 \mathrm{~h}$ and used at $1 \% \mathrm{v} / \mathrm{v}$ for each experiment. ADI specific activity was determined following standard procedures of De Angelis et al. [12] and Archibald [13].

2.4. Optimization of Process Parameters for Enhancing ADI Activity. E. faecium sp. GR7 was grown in the selected medium (TGYE) and the effect of various parameters, that is, initial $\mathrm{pH}$ (5.0 to 7.0), inoculum size ( 1 to $5 \% \mathrm{v} / \mathrm{v})$, subculturing period (1 to 4 days), incubation temperature $\left(25^{\circ} \mathrm{C}\right.$ to $50^{\circ} \mathrm{C}$ ), and culture incubation conditions, that is, aerobic, anaerobic, shaking (200 rpm) on ADI production was studied individually, by varying one factor at a time. At each step, the selected factor was included in the basal medium (selected from the previous experiment) for getting a set of conditions that enhanced ADI activity in E. faecium sp. GR7. Rest of the conditions and enzyme assays were described previously.

2.5. Effect of Various Nutrients on Enzyme Production. The effect of various carbon and nitrogen sources on enzyme production in E. faecium sp. GR7 was investigated. In the production medium, carbon of the basal media was replaced with glucose, galactose, sucrose, maltose, lactose, and fructose, and nitrogen with yeast extract, peptone, tryptone, and beef extract which were tested at levels ranging from 5 to $20 \mathrm{~g} / \mathrm{L}(\mathrm{w} / \mathrm{v})$.

2.6. Effect of Inducer Concentration. Effect of inducer concentration, that is, arginine on ADI production was studied by supplementing basal medium with different concentrations of arginine from 5 to $20 \mathrm{mM} \mathrm{(w/v)}$.

2.7. Effect of Salts and Surfactants on Enzyme Production. Basal medium was supplemented with various salts such as $\mathrm{NaCl}(0.5-5 \mathrm{~g} / \mathrm{L})(\mathrm{w} / \mathrm{v}), \mathrm{K}_{2} \mathrm{HPO}_{4}(0.5-5 \mathrm{~g} / \mathrm{L})(\mathrm{w} / \mathrm{v}), \mathrm{MnSO}_{4}$ $(0.2-2 \mathrm{mM})(\mathrm{w} / \mathrm{v}), \mathrm{CuSO}_{4}(0.025-0.075 \mathrm{mM})(\mathrm{w} / \mathrm{v}), \mathrm{ZnSO}_{4}$ $(2-6 \mathrm{mM})(\mathrm{w} / \mathrm{v})$, and surfactants including CTAB, SDS, Tween 80 , and Triton X-100 $(0.1 \% \mathrm{w} / \mathrm{v})$ to investigate their role in improving enzyme production and secretion by $E$. faecium sp. GR7.

2.8. Experimental Design. Important process variables, identified based on independent experiments, were finally used to optimize composition of the ADI production medium for E. faecium sp. GR7. RSM is a successive and exploratory tool for establishing the influence and interaction among variables on biological activities [18]. Experimental design central composite design (CCD) of RSM using Design Expert Software trial version 8.0.2 statistical software (State-Ease Inc., Minneaopolis, MN, USA) was applied for improving enzyme activity and cell densities in the LAB isolate, that is, E. faecium sp. GR7. A quadratic model obtained by a multiple regression technique for three factors, that is, tryptone, lactose, and arginine was studied at five different levels along with four constant variables, so that, interactions among these variables at different levels could be studied for two responses, that is, ADI activity and biomass (Table 1). During CCD experiments, concentrations of $\mathrm{K}_{2} \mathrm{HPO}_{4} 3 \mathrm{~g} / \mathrm{L}, \mathrm{NaCl} 1 \mathrm{~g} / \mathrm{L}, \mathrm{MnSO}_{4}$ $0.6 \mathrm{mM}$, and Tween- $801 \%, \mathrm{pH} 6.0$, and temperature $30^{\circ} \mathrm{C}$ for $24 \mathrm{~h}$ under aerobic conditions were kept as constant factors. In all the CCD experimental runs, biomass and enzyme activities were assayed using standard protocols as described previously. A total of 20 experiments were employed in CCD to estimate curvature and interaction effects of selected variables, and finally, significance of the obtained model was checked by $F$-test and goodness of fit by multiple correlation $R$ as well as determination $R^{2}$ coefficients. All design matrices were generated and analysed using Design-Expert 8.0.2 to illustrate the relationships between experimental and predicted values, and the results were depicted as $2 \mathrm{D}$ contour plots.

2.9. Experimental Validation of Statistical Model. The response surface model was validated under the predicted conditions in triplicates. On the basis of results obtained in statistical RSM analysis, the optimized medium $(\mathrm{g} / \mathrm{L})$ was composed of tryptone 15.0; lactose 10.0; arginine 20.0; $\mathrm{MnSO}_{4} 0.6 \mathrm{mM}$; $\mathrm{NaCl} 1.0 ; \mathrm{K}_{2} \mathrm{HPO}_{4}$ 3.0; Tween 80 1\%; $\mathrm{pH}-6.0$. The media were inoculated with $E$. faecium sp. GR7 $(1 \% \mathrm{v} / \mathrm{v})$ and incubated at $30^{\circ} \mathrm{C}$ for $24 \mathrm{~h}$. The samples were collected after $4 \mathrm{~h}$ intervals to estimate specific ADI activity and growth $A_{600}$ for optimized and unoptimized media basal medium.

2.10. Statistical Analysis. One way Anova analysis was carried out, and the results are presented as mean \pm standard deviation of three triplicate experiments. A probability value of $P$ value $<0.05$ was used as the criterion for statistical significance.

\section{Results and Discussion}

3.1. Selection of Basal Medium for ADI Production. MAM, MRS, TGYE, MRS (modified), Enterococcus confirmatory media, and M9 minimal salt media were selected on the basis of previous literature citations for studying ADI enzyme production in E. faecium sp. GR7. The highest specific ADI activity of $0.182 \pm 0.001 \mathrm{IU} / \mathrm{mG}$ was observed in TGYE media when supplemented with $15 \mathrm{mM}$ arginine (as shown in Figure 2), which was selected as a basal media for further study of process parameter variables on nutrients, inducers, salts, surfactants, and processing parameters on ADI production of E. faecium sp. GR7.

3.2. Effect of Initial pH, Temperature, and Culture Conditions on Arginine Production. When grown in basal media E. faecium sp. GR7 yielded maximum ADI activity of $0.187 \mathrm{IU} / \mathrm{mG}$ at $\mathrm{pH} 6.0$ when incubated at $30^{\circ} \mathrm{C}$ for $24 \mathrm{~h}$ (Figures 3 and 4 ), which was better when the cultures were kept under aerobic and stationary conditions (Figure 5).

3.3. Effect of Inoculum and Subculturing. Maximum ADI production in E. faecium sp. GR7 was reported with $2 \%$ 
TABLE 1: Variables and their levels for arginine deiminase production by E. faecium sp. GR7.

\begin{tabular}{lccccc}
\hline Factor $(\mathrm{g} / \mathrm{L})$ & $\begin{array}{c}\text { Low level star } \\
\text { point }(-\alpha)\end{array}$ & $\begin{array}{c}\text { Low level } \\
\text { factorial }(-1)\end{array}$ & $\begin{array}{c}\text { Central point } \\
(0)\end{array}$ & $\begin{array}{c}\text { High level } \\
\text { factorial }(+1)\end{array}$ & $\begin{array}{c}\text { High level star } \\
\text { point }(+\alpha)\end{array}$ \\
\hline A-tryptone & -0.23 & 0 & 15 & 30 & 40.23 \\
B-lactose & -6.82 & 0 & 10 & 20 & 26.87 \\
C-arginine & -6.82 & 0 & 10 & 20 & 26.817 \\
\hline
\end{tabular}

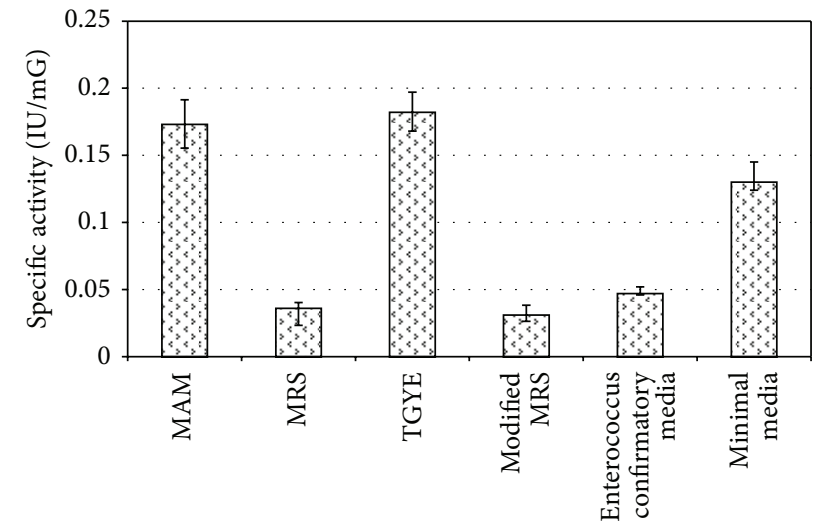

Concentration of media $(\mathrm{g} / \mathrm{L})$

FIgURE 2: Effect of culture media on specific ADI activity of $E$. faecium sp. GR7. Results are expressed as the mean \pm S.D $(n=3), P$ value $<0.05$.

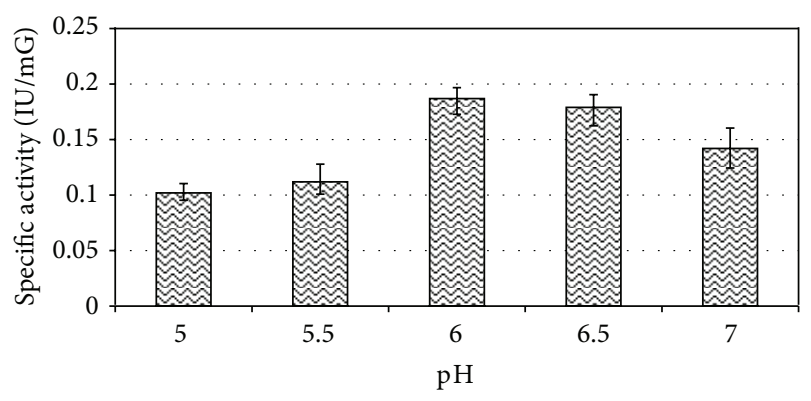

FIGURE 3: Effect of $\mathrm{pH}$ on specific ADI activity of E. faecium sp. GR7. Results are expressed as the mean \pm S.D $(n=3), P$ value $<0.05$.

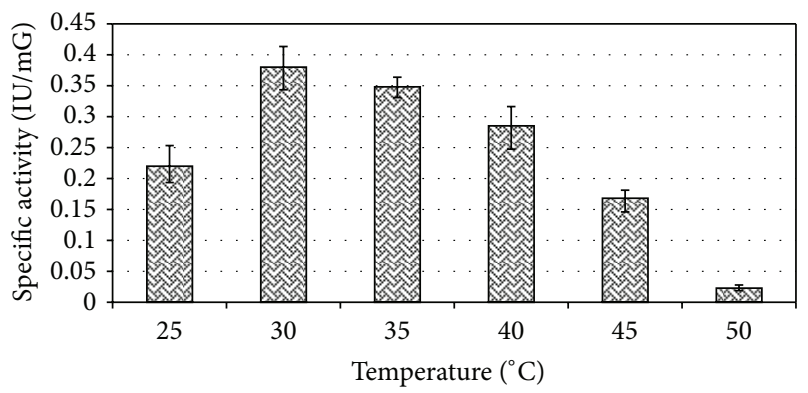

FIgURE 4: Effect of temperature on ADI enzyme production in $E$. faecium sp. GR7. Results are expressed as the mean \pm S.D $(n=3), P$ value $<0.05$.

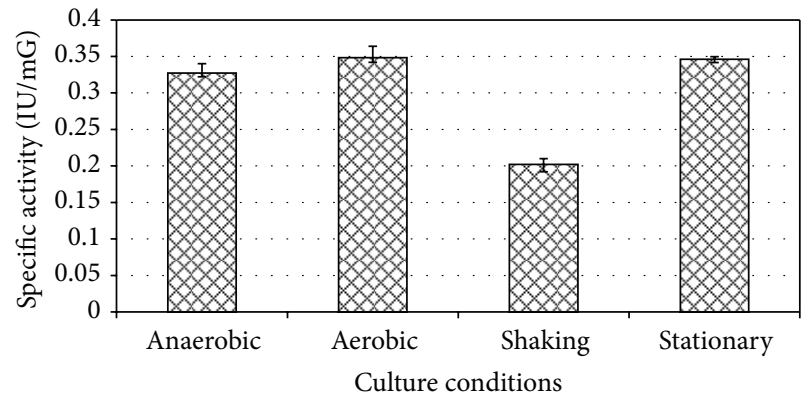

FIGURE 5: Effect of culture conditions on enzyme production. Results are expressed as the mean \pm S.D $(n=3), P$ value $<0.05$.

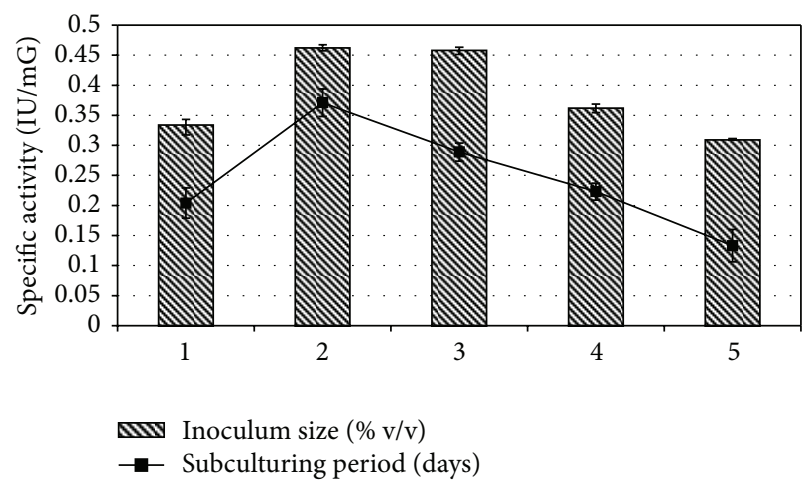

FIGURE 6: Effect of inoculum size and subculturing period on enzyme production. Results are expressed as the mean \pm S.D $(n=3)$, $P$-value $<0.05$.

$(0.462 \mathrm{IU} / \mathrm{mG})$ inoculum size and after 2 nd subculturing period (Figure 6).

3.4. Effect of Carbon and Nitrogen Sources. Among the carbon sources, lactose supported a maximum specific ADI activity at concentration $(20 \mathrm{~g} / \mathrm{L})$ of $0.131 \mathrm{IU} / \mathrm{mG}$ (Figure 7$)$. Tryptone gave maximum enzyme activity of $0.306 \mathrm{IU} / \mathrm{mG}$ at concentration of $10 \mathrm{~g} / \mathrm{L}$ (Figure 8).

3.5. Effect of Arginine. The ADI pathway is an arginine inducible system in most of the microorganisms $[5,9,12$, $25,27-29]$. In our study, maximum specific ADI activity of $0.464 \pm 0.014 \mathrm{IU} / \mathrm{mG}$ for E. faecium sp. GR7 was obtained in production media supplemented $15 \mathrm{mM}$ arginine as compared to unsupplemented basal media as shown in Figure 9. 


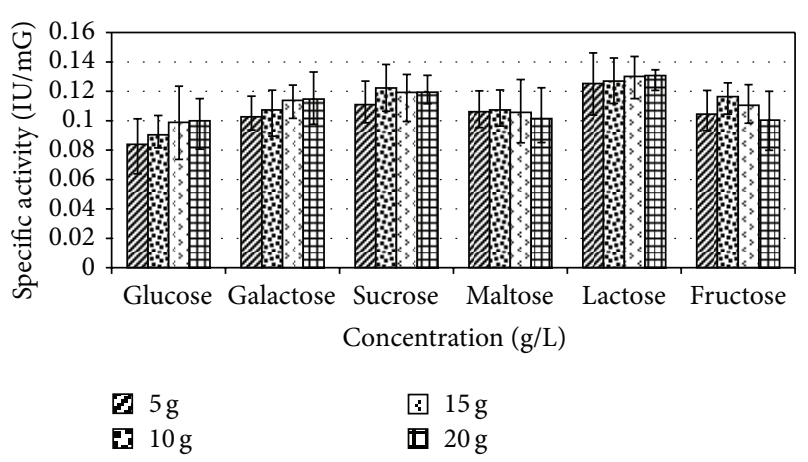

FIGURE 7: Effect of sugars on enzyme production. Results are expressed as the mean \pm S.D $(n=3), P$-value $<0.05$.

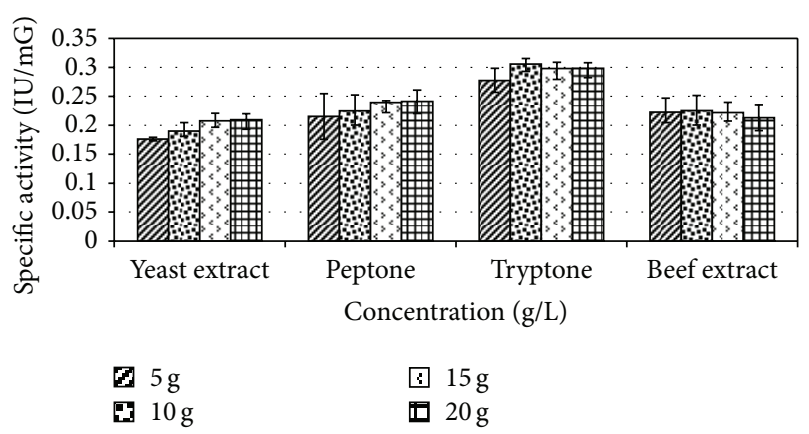

FIGURE 8: Effect of different nitrogen concentrations on enzyme production. Results are expressed as the mean \pm S.D $(n=3), P$-value $<0.05$.

3.6. Effect of Salt and Surfactants. Among varying concentrations of metal salts, that is, $\mathrm{MnSO}_{4}, \mathrm{CuSO}_{4}$, and $\mathrm{ZnSO}_{4}$, E. faecium sp. GR7 showed highest ADI activity of $0.186 \pm$ $0.010 \mathrm{IU} / \mathrm{mG}$ at the concentration of $0.6 \mathrm{mM}$ (Figure 10). ADI specific activity was also enhanced by $\mathrm{NaCl}$ and $\mathrm{K}_{2} \mathrm{HPO}_{4}$ salts (Figure 11). Among surface active agents, production media showed highest specific ADI activity $(0.318 \pm 0.012 \mathrm{IU} / \mathrm{mG})$ when supplemented with $0.1 \%$ Tween 80 (Figure 12).

A new medium including the best source of carbon, nitrogen, inducer, salts, and surfactants for ADI production was improved, and bacterium E. faecium sp. GR7 was grown in this new medium under optimized process parameters and culture conditions lactose $20 \mathrm{~g} / \mathrm{L}$; tryptone $20 \mathrm{~g} / \mathrm{L}$; arginine $15 \mathrm{mM} ; \mathrm{MnSO}_{4} 0.6 \mathrm{mM} ; \mathrm{NaCl} 1.0 \mathrm{~g} / \mathrm{L} ; \mathrm{K}_{2} \mathrm{HPO}_{4} 3 \mathrm{~g} / \mathrm{L}$; Tween $801 \%$; pH- 6.0 at $30^{\circ} \mathrm{C}$ for $24 \mathrm{~h}$ under aerobic conditions. The specific ADI activity by E. faecium sp.GR7 was enhanced to 4 folds $(0.732 \pm 0.006 \mathrm{IU} / \mathrm{mG})$ as compared to TGYE basal media $(0.182 \pm 0.001 \mathrm{IU} / \mathrm{mG})$.

3.7. Central Composite Design. A new medium was formed by selecting most influencing variables from independent experiments, which was further optimized using RSM to enhance enzyme production. In statistical tool CCD, each selected variable, that is, lactose, tryptone, and arginine while keeping $\mathrm{MnSO}_{4}, \mathrm{NaCl}, \mathrm{K}_{2} \mathrm{HPO}_{4}$, Tween 80, and $\mathrm{pH}-6$ at $30^{\circ} \mathrm{C}$ for $24 \mathrm{~h}$ under aerobic conditions as constant factors was studied at five different levels along with other variables, and therefore, the interaction among the variables at their

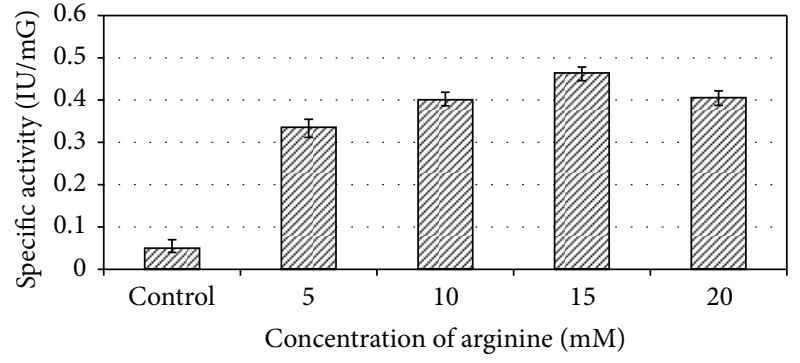

FIGURE 9: Effect of arginine (inducer) concentration on specific ADI activity of E. faecium sp. GR7. Results are expressed as the mean \pm S.D $(n=3), P$-value $<0.05$.

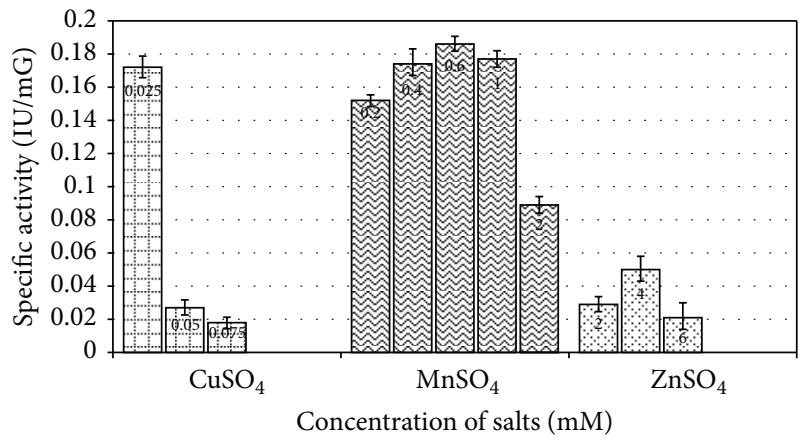

FIGURE 10: Effect of various metal ions on specific ADI activity. Results are expressed as the mean \pm S.D $(n=3), P$-value $<0.05$.

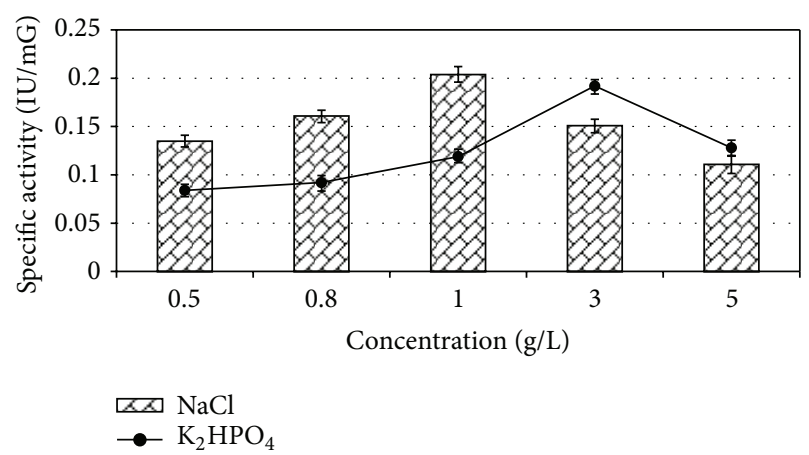

FIGURE 11: Effect of salt concentrations on specific ADI activity by E. faecium sp. GR7. Results are expressed as the mean \pm S.D $(n=3)$, $P$-value $<0.05$.

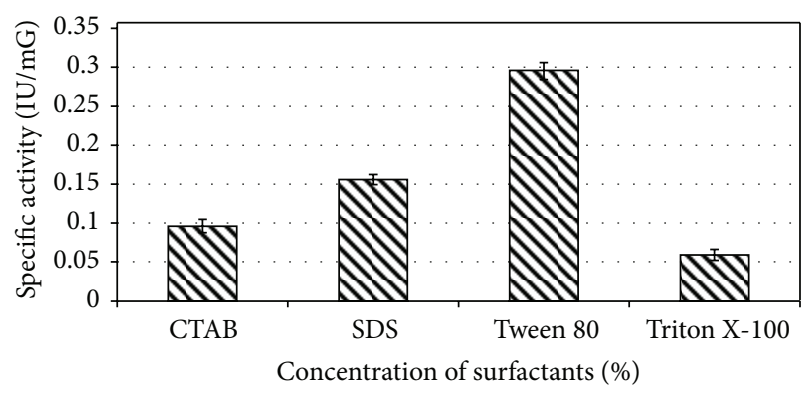

FIGURE 12: Effect of surfactants on specific ADI activity by E. faecium sp. GR7. Results are expressed as the mean \pm S.D $(n=3), P$-value $<0.05$. 
TABLE 2: Experimental design and results of central composite design for ADI specific activity and growth from E. faecium sp. GR7.

\begin{tabular}{|c|c|c|c|c|c|c|c|}
\hline \multirow{2}{*}{ Run } & \multirow{2}{*}{$\begin{array}{c}\text { Tryptone } \\
(\mathrm{g} / \mathrm{L})\end{array}$} & \multirow{2}{*}{$\begin{array}{c}\text { Lactose } \\
(\mathrm{g} / \mathrm{L})\end{array}$} & \multirow{2}{*}{$\begin{array}{c}\text { Arginine } \\
(\mathrm{g} / \mathrm{L})\end{array}$} & \multicolumn{2}{|c|}{ Growth $\left(A_{600}\right)$} & \multicolumn{2}{|c|}{ Specific activity $(\mathrm{IU} / \mathrm{mG})$} \\
\hline & & & & $\begin{array}{l}\text { Predicted } \\
\text { value }\end{array}$ & $\begin{array}{l}\text { Experimental } \\
\text { value }\end{array}$ & $\begin{array}{l}\text { Predicted } \\
\text { value }\end{array}$ & $\begin{array}{l}\text { Experimental } \\
\text { value }\end{array}$ \\
\hline 1 & 0 & 0 & 0 & 1.771 & 1.156 & 0.001 & 0.839 \\
\hline 2 & 0 & $-\alpha$ & 0 & 1.822 & 0.103 & 1.153 & 0.172 \\
\hline 3 & 0 & 0 & $+\alpha$ & 0.328 & 0.185 & 2.103 & 0.888 \\
\hline 4 & -1 & -1 & -1 & 1.706 & 0.002 & 0.083 & 0.0002 \\
\hline 5 & +1 & +1 & +1 & 0.029 & 1.607 & 3.332 & 0.643 \\
\hline 6 & -1 & +1 & -1 & 1.232 & 0.054 & 0.835 & 4.169 \\
\hline 7 & -1 & -1 & +1 & 1.232 & 0.022 & 0.835 & 2.406 \\
\hline 8 & +1 & +1 & -1 & -0.102 & 1.377 & 1.906 & 0.251 \\
\hline 9 & 0 & 0 & 0 & 1.232 & 1.249 & 0.835 & 0.839 \\
\hline 10 & +1 & -1 & -1 & 0.237 & 0.259 & 2.103 & 0.295 \\
\hline 11 & 0 & 0 & 0 & 0.548 & 1.156 & 0.261 & 0.839 \\
\hline 12 & 0 & 0 & 0 & 1.232 & 1.249 & 0.835 & 1.056 \\
\hline 13 & 0 & 0 & 0 & 1.232 & 1.26 & 0.835 & 0.779 \\
\hline 14 & $+\alpha$ & 0 & 0 & 0.149 & 2.26 & 0.761 & 0.492 \\
\hline 15 & 0 & $+\alpha$ & 0 & 1.232 & 1.276 & 1.743 & 1.272 \\
\hline 16 & +1 & 0 & +1 & 0.322 & 0.154 & 4.295 & 4.274 \\
\hline 17 & +1 & -1 & +1 & 0.029 & 0.028 & 3.399 & 4.034 \\
\hline 18 & 0 & 0 & 0 & 0.173 & 1.26 & -0.189 & 0.839 \\
\hline 19 & $-\alpha$ & 0 & 0 & 1.068 & 0.041 & 1.743 & 3.109 \\
\hline 20 & 0 & 0 & $-\alpha$ & 0.097 & 0.958 & 3.508 & 0.428 \\
\hline
\end{tabular}

different levels could be studied. When grown in unoptimized TGYE broth, E. faecium sp. GR7 showed $0.182 \mathrm{IU} / \mathrm{mG}$ of specific ADI activity with a growth of 0.823 at $A_{600 \mathrm{~nm}}$ after $24 \mathrm{~h}$ of incubation at $30^{\circ} \mathrm{C}$. In order to enhance specific ADI activity and studying growth, experiments were designed to optimize media constituents.

Results obtained were fed into Design-Expert software and analyzed using analysis of variance (ANOVA) as appropriate to the experimental design used. Based on the CCD, the experimental levels of specific ADI activity under each set of condition were determined and compared with the corresponding predicted levels suggested by Design-Expert 8.0.2 (Table 2). The maximum experimental value for ADI specific activity was $4.27 \mathrm{IU} / \mathrm{mG}$ (the average of triplicates), while the value of predicted response is $4.29 \mathrm{IU} / \mathrm{mG}$. Approximately $99 \%$ of validity was achieved, indicating the model exerted an adequate prediction on the enzyme activity. The close correlation between the experimental and predicted data indicates the appropriateness of the experimental design. The quality of the model can also be checked using various criteria. The calculated regression equation for the optimization of media constituents assessed the specific activity $(Y)$ and growth $(G)$ as a function of these variables. Multiple regression analysis of the experimental data was carried out, and statistical equation was generated which gives ADI enzyme activity and growth according to (1) and (2), respectively, as follows:

$$
\begin{aligned}
Y= & 0.8349-0.6999 * A+0.2918 * B+0.5441 * C \\
& -1.1857 * A * B+0.2609 * A * C-0.7642 * B * C \\
& +0.5288 * A^{2}+0.1475 * B^{2}+0.1248 * C^{2},
\end{aligned}
$$

$$
\begin{aligned}
G= & 1.2325+0.5127 * A+0.3384 * B-0.0850 * C \\
& +0.3116 * A * B+0.0138 * A * C+0.0386 * B * C \\
& -0.0965 * A^{2}-0.2595 * B^{2}-0.3012 * C^{2}
\end{aligned}
$$

where $Y$ represents specific enzyme activity, $G$ represents growth, and $A, B, C$ are coded values of tryptone, lactose, and arginine, respectively. Tables 5 and 6 show ANOVA results for the RSM quadratic model for $Y$ and $G$ are responses, respectively. According to the present model $A, C, A B, B C, A^{2}$ are significant model terms for $Y$ response, and $A, B, A B, B^{2}$, $C^{2}$ are significant model terms for $G$ response, respectively.

Quadratic model was found to be the "best fit model" for the specific enzyme activity also for growth with the highest $F$-value when compared to other models (Table 3 ). ANOVA for ADI specific activity $(Y, I U / m G)$ indicated the " $P$-value" to be 0.0018 , which implies the model to be significant. The "lack of fit $F$-value" of 99.43 with $P$-value $<0.0001$ implies that the lack of fit is significant. There is only a $0.01 \%$ chance that a "lack of fit $F$-value" this large could occur due to noise. ANOVA indicated the $R_{2}$ value of 0.8745 for response $Y$. This ensures a good correlation between observed and expected values of the quadratic model and indicates that this model could explain $87 \%$ response variability. The adequate precision which measures the signal-to-noise ratio of 9.227 indicates an adequate signal.

Quadratic model is also found to be the "best fit model" for the growth at $A_{600}$ with the highest $F$-value when compared to other models (Table 4). ANOVA for ADI growth $(G$, $\left.A_{600}\right)$ indicated the " $P$-value" to be 0.0004 , which implies the 
TABLE 3: Model fit summary for the growth.

\begin{tabular}{|c|c|c|c|c|c|c|}
\hline Source & Sum of squares & Degree of freedom & Mean square & $F$ value & $P$ value & Prob $>F$ \\
\hline Mean versus total & 12.29 & 1 & 12.29 & & & \\
\hline Linear versus mean & 5.25 & 3 & 1.75 & 7.57 & 0.0023 & \\
\hline 2FI versus linear & 0.79 & 3 & 0.26 & 1.18 & 0.3567 & \\
\hline Quadratic versus 2FI & 2.11 & 3 & 0.70 & 8.70 & 0.0039 & Suggested \\
\hline Cubic versus quadratic & 0.43 & 4 & 0.11 & 1.70 & 0.2674 & Aliased \\
\hline Residual & 0.38 & 6 & 0.06 & & & \\
\hline Total & 21.24 & 20 & 1.06 & & & \\
\hline
\end{tabular}

TABLE 4: Model fit summary for ADI specific activity.

\begin{tabular}{|c|c|c|c|c|c|c|}
\hline Source & Sum of squares & Degree of freedom & Mean square & $F$ value & $P$ value & Prob $>F$ \\
\hline Mean versus total & 38.20 & 1 & 38.20 & & & \\
\hline Linear versus mean & 11.90 & 3 & 3.97 & 2.50 & 0.0963 & \\
\hline 2FI versus linear & 16.47 & 3 & 5.49 & 8.02 & 0.0028 & Suggested \\
\hline Quadratic versus 2FI & 4.22 & 3 & 1.41 & 3.01 & 0.0811 & Suggested \\
\hline Cubic versus quadratic & 1.81 & 4 & 0.45 & 0.95 & 0.4966 & Aliased \\
\hline Residual & 2.86 & 6 & 0.48 & & & \\
\hline Total & 75.46 & 20 & 3.77 & & & \\
\hline
\end{tabular}

TABLE 5: Regression analysis (ANOVA) for the growth.

\begin{tabular}{|c|c|c|c|c|c|c|}
\hline Source & Sum of squares & Degree of freedom & Mean squares & $F$ value & $P$ value & Prob $>F$ \\
\hline Model & 8.150 & 9 & 0.960 & 11.228 & 0.0004 & Significant \\
\hline A-tryptone & 3.591 & 1 & 3.591 & 44.527 & $<0.0001$ & \\
\hline B-lactose & 1.564 & 1 & 1.564 & 19.395 & 0.0013 & \\
\hline C-arginine & 0.099 & 1 & 0.099 & 1.224 & 0.2945 & \\
\hline $\mathrm{AB}$ & 0.777 & 1 & 0.777 & 9.633 & 0.0112 & \\
\hline $\mathrm{AC}$ & 0.002 & 1 & 0.002 & 0.019 & 0.8928 & \\
\hline $\mathrm{BC}$ & 0.012 & 1 & 0.012 & 0.148 & 0.7085 & \\
\hline $\mathrm{A}^{\wedge} 2$ & 0.134 & 1 & 0.134 & 1.664 & 0.2260 & \\
\hline $\mathrm{B}^{\wedge} 2$ & 0.970 & 1 & 0.970 & 12.034 & 0.0060 & \\
\hline $\mathrm{C}^{\wedge} 2$ & 1.308 & 1 & 1.308 & 16.241 & 0.0024 & \\
\hline Residual & 0.806 & 10 & 0.081 & & & \\
\hline Lack of fit & 0.793 & 5 & 0.159 & 60.763 & $<0.0002$ & Significant \\
\hline Pure error & 0.013 & 5 & 0.003 & & & \\
\hline Cor total & 8.956 & 9 & & & & \\
\hline
\end{tabular}

Coefficient of determination $\left(R^{2}\right)=0.909$.

TABLE 6: Regression analysis (ANOVA) for ADI specific activity.

\begin{tabular}{lccccc}
\hline Source & Sum of squares & Degree of freedom & Mean squares & $F$ value & $P$ value \\
\hline Model & 32.586 & 9 & 3.621 & 7.749 & 0.0018 \\
A-tryptone & 6.692 & 1 & 6.692 & 14.321 & 0.0036 \\
B-lactose & 1.163 & 1 & 1.163 & 2.489 & 0.1457 \\
C-arginine & 4.043 & 1 & 4.043 & 8.653 & 0.0147 \\
$\mathrm{AB}$ & 11.249 & 1 & 11.249 & 24.074 & 0.0006 \\
$\mathrm{AC}$ & 0.545 & 1 & 0.545 & 1.166 & 0.3056 \\
$\mathrm{BC}$ & 4.673 & 1 & 4.673 & 10.001 & 0.0101 \\
$\mathrm{~A}^{\wedge} 2$ & 4.030 & 1 & 4.030 & 8.625 & 0.0149 \\
$\mathrm{~B}^{\wedge} 2$ & 0.314 & 1 & 0.314 & 0.671 & 0.4317 \\
$\mathrm{C}^{\wedge} 2$ & 0.225 & 1 & 0.225 & 0.481 & 0.5038 \\
Residual & 4.673 & 10 & 0.467 & & \\
Lack of fit & 4.626 & 5 & 0.925 & 99.432 & $<0.0001$ \\
Pure error & 0.047 & 5 & 0.009 & & Significant \\
Cor total & 37.258 & 19 & & & \\
\hline
\end{tabular}

Coefficient of determination $\left(R^{2}\right)=0.874$. 
model to be significant. The "lack of fit $P$-value" of $<0.0002$ implies the lack of fit is significant. There is only a $0.02 \%$ chance that a "lack of fit $F$-value" this large could occur due to noise. A 91\% response variability showed good correlation between observed and expected values of the quadratic model as ANOVA indicated the $R^{2}$ value of 0.9099 for response $Y$. The adequate precision which measures the signal-to-noise ratio of 9.58 indicates an adequate signal.

E. faecium sp. GR7 shows very poor specific ADI activity $(0.182 \pm 0.001 \mathrm{IU} / \mathrm{mG})$ in unoptimized TGYE broth, which was enhanced to $0.732 \pm 0.006 \mathrm{IU} / \mathrm{mG}$ in new media and finally raised to 15 folds $(4.27 \mathrm{IU} / \mathrm{mG})$ in RSM optimized media (run 16) as shown in Table 2. The 2D contour plots based on the interactions between these variables show correlation between increase in specific ADI activity versus concentration of each variable that reaches the optimum level of enzyme activity and growth at concentration (g/L) lactose 10; tryptone 15; arginine 20 beyond which a decline was observed (Figures 13(d), 13(e), and 13(f)). 2D contour plots were obtained by plotting any two variables on $x$ and $y$-axis while keeping the other third variable at their central value, that is, lactose $10 \mathrm{~g} / \mathrm{L}, 15 \mathrm{~g} / \mathrm{L}$ tryptone, and arginine $10 \mathrm{~g} / \mathrm{L}$. CCD employed has revealed that tryptone at concentration of $15 \mathrm{~g} / \mathrm{L}$ was optimal for maximum enzyme activity. This nitrogen source plays important role in ADI specific activity and biomass production, as growth increases with the concomitant increase in tryptone concentration (Figures 13(a), 13(b), 13(d), and 13(e)). Results indicate a central value of lactose as $10 \mathrm{~g} / \mathrm{L}$ for optimal enzyme production. In present study, similar effect was observed in case of lactose, as the concentration of lactose increases their is an increase in biomass production (Figures 13(a) and 13(c)). But it represses ADI enzyme activity as its concentration increases beyond $10 \mathrm{~g} / \mathrm{L}$ (Figures 13(d) and 13(f)). Concentration of arginine in the culture medium also has profound effect on specific activity of arginine deiminase (Figures 13(e) to 13(f)), but it is not required for bacterial growth.

E. faecium sp. GR7 when grown in media containing different nutrients resulted in different growth profiles. The growth $\left(A_{600}\right)$ was mostly influenced by an increase in the concentration of tryptone and lactose (Figure 13(a)). Presence of arginine in the culture medium has a least contribution towards growth of E. faecium sp. GR7 (Figures 13(b) and 13(c)), although it is important for inducing ADI activity (Figures 13(e) and 13(f)). Based on the results obtained, optimized medium designed with the components $(\mathrm{g} / \mathrm{L})$ tryptone 15; lactose 10; arginine 20; $\mathrm{NaCl} 1.0 ; \mathrm{K}_{2} \mathrm{HPO}_{4} 3.0 ; \mathrm{MnSO}_{4}$ $0.6 \mathrm{mM}$; Tween 80 1\%; pH-6.0 at $30^{\circ} \mathrm{C}$ for $24 \mathrm{~h}$ under aerobic conditions. Figure 14 illustrates comparative growth profiles of the E. faecalis strain in basal (TGYE) and optimal media. Biomass concentration of the bacteria cultivated in optimal medium in batch culture conditions reached 0.751 at $A_{600}$ $(12.1 \mathrm{mg} / \mathrm{L})$ after $20 \mathrm{~h}$ of incubation with concomitant production of $4.27 \mathrm{IU} \mathrm{mG}^{-1} \mathrm{IU} / \mathrm{mG}$ specific ADI activity. This being higher in comparison with bacteria in TGYE medium with 0.32 at $A_{600}(5.17 \mathrm{mg} / \mathrm{L})$ biomass after $20 \mathrm{~h}$ of incubation with specific ADI activity of $0.20 \mathrm{IU} / \mathrm{mG}$. Though the biomass yield is lesser in optimized medium but higher specific ADI activity is having more significance from industrial perspective.

\section{Discussion}

ADI pathway of bacteria provides number of functions such as sole energy provider (ATP) for the growth of a variety of microorganisms in various environmental conditions, especially arginine as main catabolite for nonfermenting bacteria, allowing anaerobic growth of strict aerobic bacteria, growth of fermentative bacteria when sugars are not available or at low sugar concentration, to supply carbamoyl phosphate for biosynthesis of citrulline or pyrimidines and to protect bacteria against acid or starvation environmental stress conditions [12, 30]. Therefore, expression of ADI pathway is widely reported among prokaryotic organisms including prominent bacterial species such as Clostridium [19], Enterococcus [20], Halobacterium [31], Lactobacillus [21], Lactococcus [6], Leuconostoc [7], Mycoplasma [22], Pseudomonas [25], Streptococcus [26], and Weissella [27]. Arginine catabolism by the ADI pathway has been explored in several industrial lactic acid bacterial species, mainly regarding their genetic and physiological aspect and enzymology of the ADI pathway. The increase in acid resistance of homofermentative and heterofermentative $\mathrm{LAB}$ may be due to the restoration of the optimum intercellular $\mathrm{pH}$ through arginine utilization and ammonia production [12]. Few reports emphasizing the role of the media constituents for enhancing ADI activity in bacterial species are available [23, 24, 27]. More knowledge about the influence of media components on ADI production, especially in GRAS LAB, is desired, which populate different food environments. In the present work, production of arginine deiminase in E. faecium sp. GR7 was enhanced to 4 folds in fermentation media (EAPM) using independent experiments which was further raised by 15 folds in RSM optimized media supplemented with $15 \mathrm{mM}$ arginine in comparison to basal medium. Specific ADI activities reported in GRAS LAB range from 0.10 to $2.80 \mathrm{IU} / \mathrm{mG}$ (Table 7). Previous reports on Lactobacillus buchneri CUC-3 [32], Lactobacillus buchneri $\mathrm{NCDO}_{110}$ [29], Lactobacillus sanfranciscensis $\mathrm{CB1}$ [12], Streptococcus lactis [9], Weissella confusa GR7 [27], Weissella koreensis MSI-3 [10], and Weissella koreensis MSI-14 [10] have suggested the role of arginine in enhancing ADI activity in various LAB strains. Although, arginine contributes little to the growth of E. faecium sp. GR7 but its involvement in induction of ADI activity is reported in the present study. The nature as well as concentration of the sugars was found to affect ADI production in case of lactose metabolizing $E$. faecium sp. GR7. Other sugars such as glucose, galactose, sucrose, maltose, and fructose did not suppress induction of ADI which was reported earlier in other LAB strains such as Lactobacillus buchneri $\mathrm{NCDO}_{110}$ (glucose) [29], Lactobacillus sake (above $0.6 \mathrm{mM}$ glucose) [31], Lactobacillus sanfranciscensis CB1 (above $54 \mathrm{mM}$ glucose) [12], and Streptococcus lactis (glucose, lactose) [9]. Fructose was known to suppress ADI activity in Leuconostoc oenos, Streptococcus mitis, and Weissella confusa GR7 [27, 33, 34]. Tryptone showed highest ADI production in E. faecium sp. GR7 at $(10 \mathrm{~g} / \mathrm{L})$ which was approximately 11.57 and 8.05 times higher than yeast extract, 


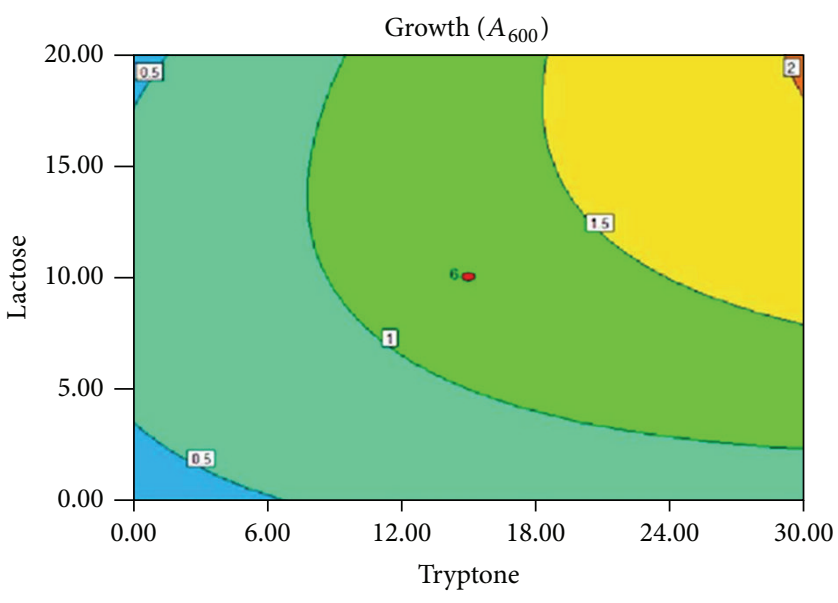

(a)

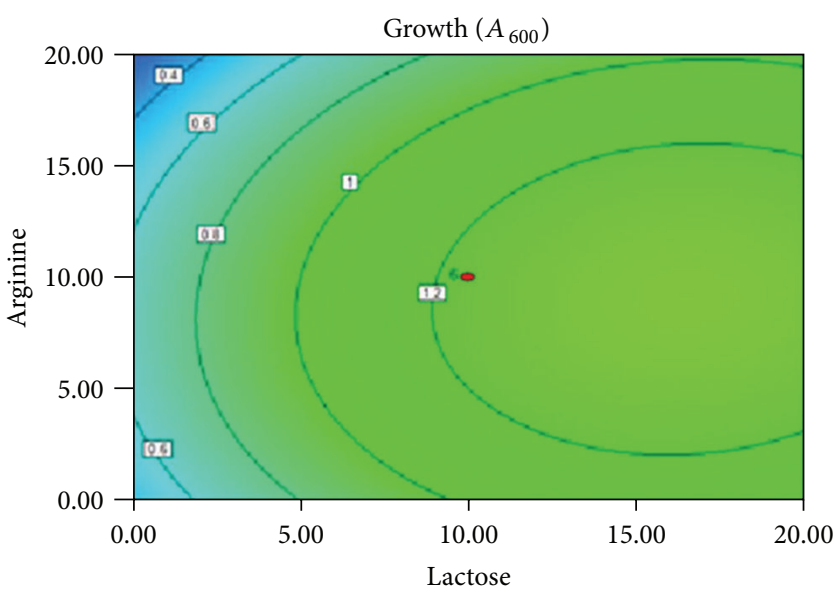

(c)

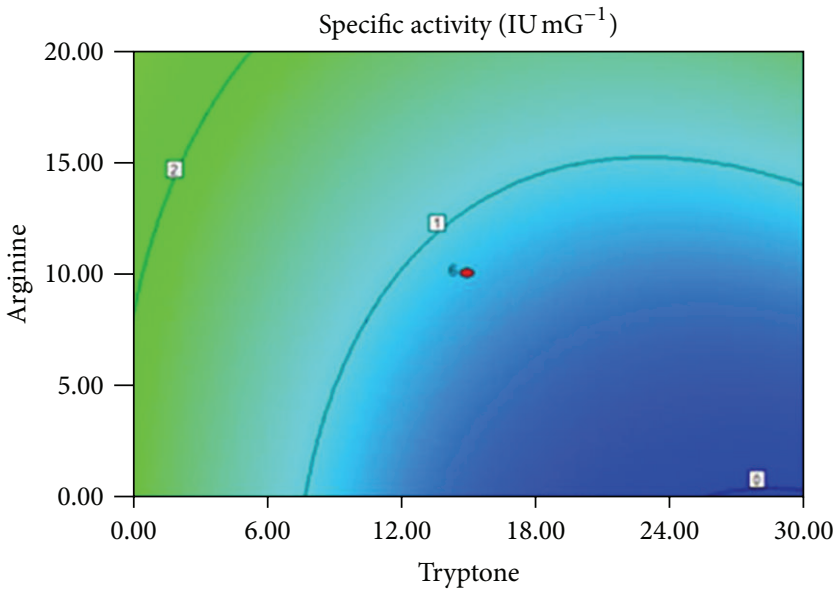

(e)

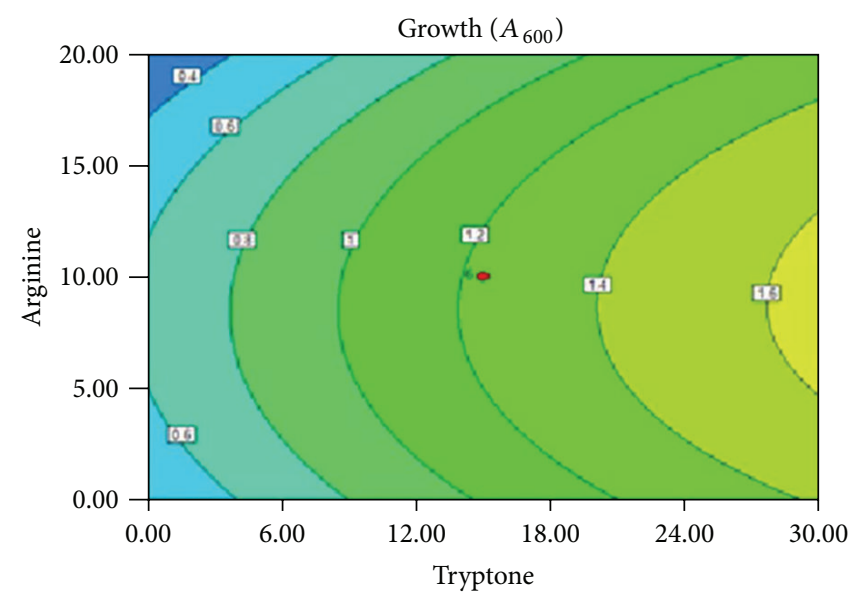

(b)

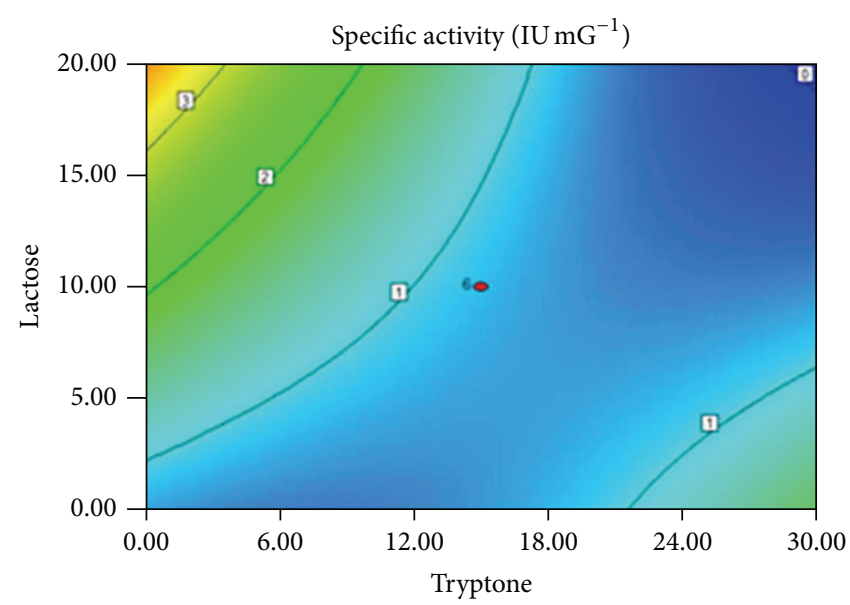

(d)

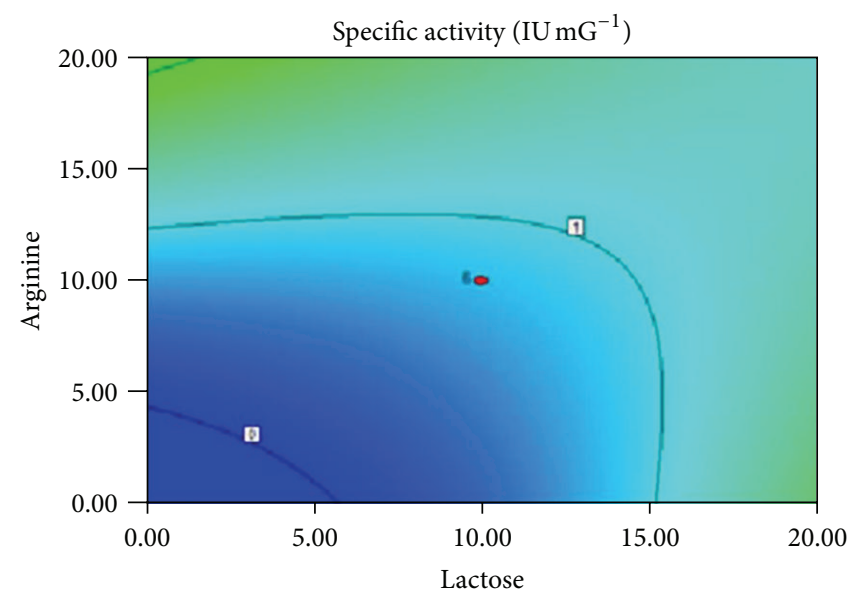

(f)

Figure 13: 2D contour plot showing effects and interaction of (a) lactose $(\mathrm{g} / \mathrm{L})$ and tryptone $(\mathrm{g} / \mathrm{L})(\mathrm{b})$ arginine $(\mathrm{g} / \mathrm{L})$ and tryptone $(\mathrm{g} / \mathrm{L})(\mathrm{c})$ arginine $(\mathrm{g} / \mathrm{L})$ and lactose $(\mathrm{g} / \mathrm{L})$ on growth at $A_{600}$ of E. faecium isolate GR7 and $(\mathrm{d})$ lactose $(\mathrm{g} / \mathrm{L})$ and tryptone $(\mathrm{g} / \mathrm{L})(\mathrm{e})$ arginine $(\mathrm{g} / \mathrm{L})$ and tryptone (g/L) (f) arginine (g/L) and lactose (g/L) on specific ADI activity of E. faecium sp. GR7. 
TABLE 7: Specific ADI activity in different microorganisms.

\begin{tabular}{|c|c|c|}
\hline Native microorganism & $\begin{array}{c}\text { Specific ADI activity } \\
\text { (IU/mG) }\end{array}$ & Reference \\
\hline Clostridium sporogenes & 2.0 & {$[19]$} \\
\hline Enterococcus faecalis NJ402 & 0.238 & {$[20]$} \\
\hline Halobacterium salinarum & $0.33 \mathrm{nKat} / \mathrm{mg}$ & {$[31]$} \\
\hline Lactobacillus sake & $1.5 \mathrm{U} / \mathrm{mL}$ & {$[21]$} \\
\hline Lactobacillus buchneri CUC-3 & 1.01 & {$[7]$} \\
\hline L. sanfranciscensis $\mathrm{CB} 1$ & $\begin{array}{l}16.20 \text { (from } 10 \text { times } \\
\text { concentrated suspension) }\end{array}$ & {$[12]$} \\
\hline Lactococcus lactis ssp. lactis ATCC 7962 & 2.16 & {$[6]$} \\
\hline Leuconostoc oenos OENO & 0.10 & {$[7]$} \\
\hline Mycoplasma arginini ATCC 23243 & 1.91 & \\
\hline Mycoplasma arginini G-230 & 1.37 & \\
\hline Mycoplasma arginini strain leonis & 0.78 & \\
\hline Mycoplasma arthritidis & 1.2 & \\
\hline Mycoplasma fermentans & 0.28 & [22] \\
\hline Mycoplasma gallinarum & 1.3 & \\
\hline Mycoplasma hominis ATCC 14027 & 2.0 & \\
\hline Mycoplasma hominis & 2.9 & \\
\hline \multicolumn{3}{|l|}{ Pseudomonas plecoglossicida CGMCC2039 } \\
\hline \multicolumn{3}{|l|}{ Wild type strain } \\
\hline Before media optimization & $0.96 \mathrm{U} / \mathrm{mL}$ & \\
\hline After media optimization & $1.6 \mathrm{U} / \mathrm{mL}$ & {$[23]$} \\
\hline \multicolumn{3}{|l|}{ Mutant strain } \\
\hline At $\mathrm{pH} 6.0$ & 16.7 & \\
\hline At $\mathrm{pH} 6.5$ & 21.7 & {$[24]$} \\
\hline Pseudomonas putida & 1.52 & {$[25]$} \\
\hline Streptococcus faecalis 13398 & 1.60 & {$[26]$} \\
\hline Streptococcus faecium A-2 & 0.11 & {$[26]$} \\
\hline Streptococcus lactis ML3 & 0.28 & {$[9]$} \\
\hline \multicolumn{3}{|l|}{ Weissella confusa GR7 } \\
\hline Before media optimization & 0.27 & \\
\hline After media optimization & 2.808 & {$[27]$} \\
\hline \multicolumn{3}{|l|}{ Enterococcus faecium GR7 } \\
\hline Before media optimization & 0.182 & \multirow{2}{*}{ Present research work } \\
\hline After media optimization & 4.27 & \\
\hline
\end{tabular}

and peptone respectively, as reported earlier in E. faecalis NJ402 [21]. ADI pathways also exhibit salt dependence as $\mathrm{MnSO}_{4}, \mathrm{NaCl}$, and $\mathrm{K}_{2} \mathrm{HPO}_{4}$ are reported to magnify their activity [35].

Conventional processes of optimization are usually time consuming and expensive. The single factor optimization cannot explain the actual interactions of the parameters of the experimental data because the interaction between different factors is overlooked, leading to a misinterpretation of the results. In this study, optimization of multiple factors yielded more accurate results from which one could choose the correct value of each response factor individually with a high certainty. Fermentation media (EAPM) optimized using single factor based independent experiments resulted in 4-fold increase in ADI specific activity; however, a 15-fold increase was observed in RSM optimized medium when compared with basal medium. The optimized media components could be selected as the best condition for further studies on the development of a cost effective and viable industrial fermentation process. Thus, this work demonstrated the advantage of statistical media optimization methods for enzyme production with a minimum number of experimental trials, simultaneously with a reduction in laborious and time-consuming media composition analysis strategies.

\section{Conclusion}

A new strain of an Enterococcus was found to be a potential producer of ADI enzyme. In this study, result of bioprocess was optimized for future scaleup of ADI production process in E. faecium sp. GR7. A statistical strategy of CCD was used successfully to find out optimum values of significant response factors, which resulted in 15-fold increase in ADI production in RSM optimized media over basal media in 


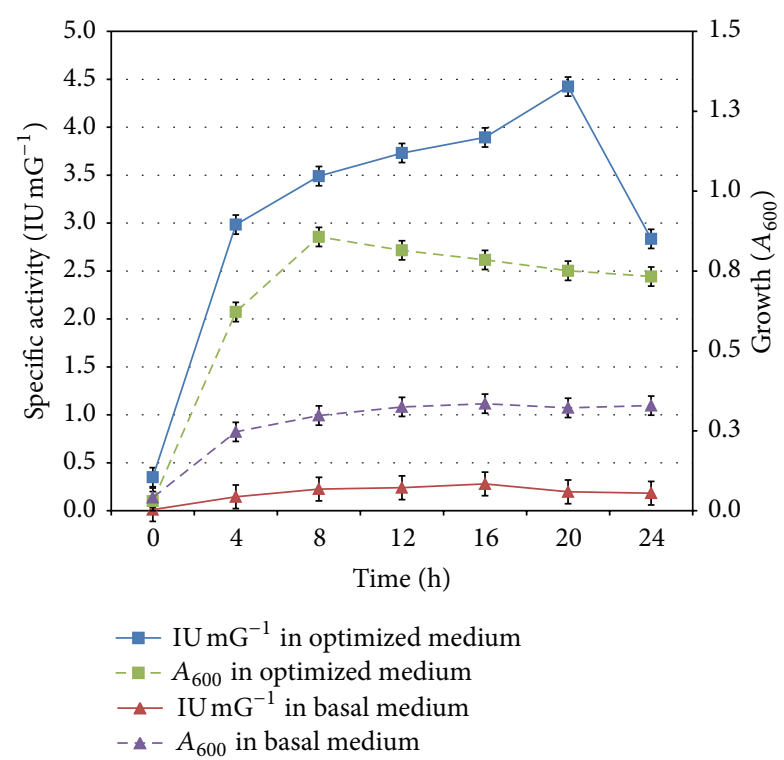

FIgURE 14: Time course of specific ADI activity and growth of $E$. faecium sp. GR7 in optimized and basal (TGYE) medium. Results are expressed as the mean \pm S.D $(n=3), P$-value $<0.05$.

E. faecium sp. GR7. It is interesting to report a novel lactic acid bacterial strain; that is, E. faecium having arginine metabolizing capacity can be ideally explored for production as a class of therapeutic enzyme against arginine auxotrophic cancers at low cost where the industrial needs are satisfied. The progress in the ADI research will undoubtedly facilitate the use of amino acid depriving enzymes in an innovative strategy in therapy of specific auxotrophic tumors and have profound influence on human health.

\section{Conflict of Interests}

The authors declare no conflict of interests.

\section{Acknowledgments}

Authors acknowledge UGC, New Delhi and Government of India for funding and Maulana Azad National Fellowship for Minority Students no. F.40-116(M/S)/2009(SA-III/MANF).

\section{References}

[1] M. Ikeda, S. Mitsuhashi, K. Tanaka, and M. Hayashi, "Reengineering of a corynebacterium glutamicum L-arginine and Lcitrulline producer," Applied and Environmental Microbiology, vol. 75, no. 6, pp. 1635-1641, 2009.

[2] T. Utagawa, "Production of arginine by fermentation," Journal of Nutrition, vol. 134, no. 10, pp. 28545-28575, 2004.

[3] M. Zúñiga, M. M. C. Miralles, and G. Pérez-Martínez, “The product of $\operatorname{arcR}$, the sixth gene of the arc operon of Lactobacillus sakei, is essential for expression of the arginine deiminase pathway," Applied and Environmental Microbiology, vol. 68, no. 12, pp. 6051-6058, 2002.
[4] A. Galkin, L. Kulakova, E. Sarikaya, K. Lim, A. Howard, and O. Herzberg, "Structural insight into arginine degradation by arginine deiminase, an antibacterial and parasite drug target," The Journal of Biological Chemistry, vol. 279, no. 14, pp. 14001-14008, 2004.

[5] B. Barcelona-Andrés, A. Marina, and V. Rubio, "Gene structure, organization, expression, and potential regulatory mechanisms of arginine catabolism in Enterococcus faecalis," Journal of Bacteriology, vol. 184, no. 22, pp. 6289-6300, 2002.

[6] J. E. Kim, D. W. Jeong, and H. J. Lee, "Expression, purification, and characterization of arginine deiminase from Lactococcus lactis ATCC 7962 in Escherichia coli BL21," Protein Expression and Purification, vol. 53, no. 1, pp. 9-15, 2007.

[7] S. Q. Liu, G. G. Pritchard, M. J. Hardman, and G. J. Pilone, "Arginine catabolism in wine lactic acid bacteria: is it via the arginine deiminase pathway or the arginase-urease pathway?" Journal of Applied Bacteriology, vol. 81, no. 5, pp. 486-492, 1996.

[8] R. M. de Orduna, M. L. Patchett, S. Q. Liu, and G. J. Pilone, "Growth and arginine metabolism of the wine lactic acid bacteria Lactobacillus buchneri and Oenococcus oeni at different $\mathrm{pH}$ values and arginine concentrations," Applied and Environmental Microbiology, vol. 67, no. 4, pp. 1657-1662, 2001.

[9] V. L. Crow and T. D. Thomas, "Arginine metabolism in lactic Streptococci," Journal of Bacteriology, vol. 150, no. 3, pp. 10241032, 1982.

[10] J. J. Yu and S. H. Oh, "Isolation and characterization of lactic acid bacteria strains with ornithine producing capacity from natural sea salt," Journal of Microbiology, vol. 48, no. 4, pp. 467472, 2010.

[11] M. Kennedy and D. Krouse, "Strategies for improving fermentation medium performance: a review," Journal of Industrial Microbiology and Biotechnology, vol. 23, no. 6, pp. 456-475, 1999.

[12] M. de Angelis, L. Mariotti, J. Rossi et al., "Arginine catabolism by sourdough lactic acid bacteria: purification and characterization of the arginine deiminase pathway enzymes from Lactobacillus sanfranciscensis CB1," Applied and Environmental Microbiology, vol. 68, no. 12, pp. 6193-6201, 2002.

[13] R. M. Archibald, "Determination of citrulline and allantoin and demonstration of citrulline in blood plasma," The Journal of Biological Chemistry, vol. 156, pp. 121-142, 1944.

[14] J. C. de Man, M. Rogosa, and M. E. Sharpe, "A medium for the cultivation of lactobacilli," Journal of Applied Bacteriology, vol. 23, pp. 130-135, 1960.

[15] R. M. Shekh and U. Roy, "Biochemical characterization of an anti-Candida factor produced by Enterococcus faecalis," BMC Microbiology, vol. 12, pp. 132-147, 2012.

[16] M. S. Edwards and C. J. Baker, Principles and Practice of Infectious Diseases, Churchill Livingstone, New York, NY, USA, 3rd edition, 1990.

[17] L. G. Davis, M. D. Dibner, and J. F. Battey, Basic Methods in Molecular Biology, Elsevier, New York, NY, USA, 1986.

[18] V. Dandavate, J. Jinjala, H. Keharia, and D. Madamwar, "Production, partial purification and characterization of organic solvent tolerant lipase from Burkholderia multivorans V2 and its application for ester synthesis," Bioresource Technology, vol. 100, no. 13, pp. 3374-3381, 2009.

[19] V. Venugopal and G. B. Nadkarni, "Regulation of the arginine dihydrolase pathway in Clostridium sporogenes," Journal of Bacteriology, vol. 131, no. 2, pp. 693-695, 1977. 
[20] J. Li, Y. Cao, S. Qian, Y. Liu, L. Qian, and Q. Jiao, "Study on fermentation process of arginine deiminase producing strain," Chinese Journal of Chemical Engineering, vol. 22, no. 1, pp. 4347.

[21] M. C. Montel and M. C. Champomier, "Arginine catabolism in Lactobacillus sake isolated from meat," Applied and Environmental Microbiology, vol. 53, no. 11, pp. 2683-2685, 1987.

[22] J. D. Fenske and G. E. Kenny, "Role of arginine deiminase in growth of Mycoplasma hominis," Journal of Bacteriology, vol. 126, no. 1, pp. 501-510, 1976.

[23] Y. M. Liu, Z. H. Sun, Y. Ni, P. Zheng, Y. P. Liu, and F. J. Meng, "Isolation and identification of an arginine deiminase producing strain Pseudomonas plecoglossicida CGMCC2039," World Journal of Microbiology and Biotechnology, vol. 24, no. 10, pp. 2213-2219, 2008.

[24] Y. Ni, Y. Liu, U. Schwaneberg et al., "Rapid evolution of arginine deiminase for improved anti-tumor activity," Applied Microbiology and Biotechnology, vol. 90, no. 1, pp. 193-201, 2011.

[25] T. Shibatani, T. Kakimoto, and I. Chibata, "Crystallization and properties of L-arginine deiminase of Pseudomonas putida," The Journal of Biological Chemistry, vol. 250, no. 12, pp. 4580-4583, 1975.

[26] J. K. Mackey Jr. and R. W. Beck, "Activities of arginine dihydrolase and phosphatase in Streptococcus faecalis and Streptococcus faecium," Applied Microbiology, vol. 16, no. 10, pp. 1543-1547, 1968.

[27] B. Kaur and R. Kaur, "Statistical screening of media components for the production of arginine deiminase by Weissella confusa GR7," International Journal Food Fermentation Technology, vol. 2, no. 3, pp. 81-89, 2012.

[28] T. Rimaux, A. Rivière, K. Illeghems, S. Weckx, L. de Vuyst, and F. Leroy, "Expression of the arginine deiminase pathway genes in Lactobacillus sakei is strain dependent and is affected by the environmental pH," Applied Environmental Microbiology, vol. 78, no. 14, pp. 4874-4883, 2012.

[29] M. C. M. de Nadra, A. A. P. de Ruiz Holgado, and G. Oliver, "Arginine dihydrolase pathway on Lactobacillus buchneri: a review, Biochimie, vol. 70, no. 3, pp. 367-374, 1988.

[30] A. Casiano-Colon and R. E. Marquis, "Role of the arginine deiminase system in protecting oral bacteria and an enzymatic basis for acid tolerance," Applied and Environmental Microbiology, vol. 54, no. 6, pp. 1318-1324, 1988.

[31] G. M. Monstadt and A. W. Holldorf, "Arginine deiminase from Halobacterium salinarium. Purification and properties," Biochemical Journal, vol. 273, no. 3, pp. 739-745, 1991.

[32] R. M. de Orduña, S. Q. Liu, M. L. Patchett, and G. J. Pilone, "Ethyl carbamate precursor citrulline formation from arginine degradation by malolactic wine lactic acid bacteria," FEMS Microbiology Letters, vol. 183, no. 1, pp. 31-35, 2000.

[33] S. Q. Liu, G. G. Pritchard, M. J. Hardman, and G. J. Pilone, "Occurrence of arginine deiminase pathway enzymes in arginine catabolism by wine lactic acid bacteria," Applied and Environmental Microbiology, vol. 61, no. 1, pp. 310-316, 1995.

[34] B. Y. Hiraoka, M. Mogi, K. Fukasawa, and M. Harada, "Coordinate repression of arginine aminopeptidase and three enzymes of the arginine deiminase pathway in Streptococcus mitis," Biochemistry International, vol. 12, no. 6, pp. 881-887, 1986.

[35] J. Li, Y. Cao, Y. Liu, S. Qian, and Q. Jiao, "Activity and stability of arginine deiminase for producing L-citrulline," Chinese Journal of Chemical Engineering, vol. 13, no. 6, pp. 841-844, 2005. 

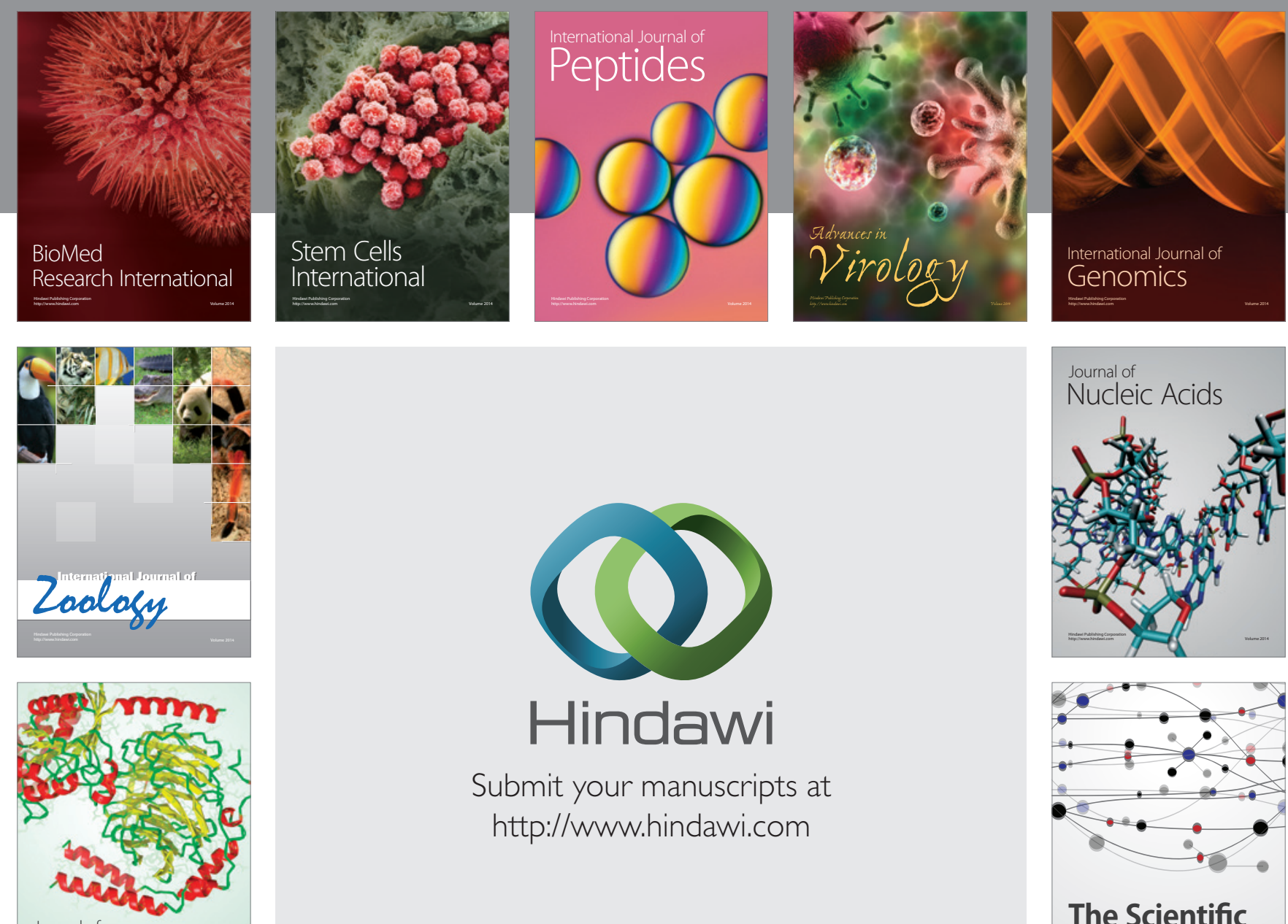

Submit your manuscripts at

http://www.hindawi.com

Journal of
Signal Transduction
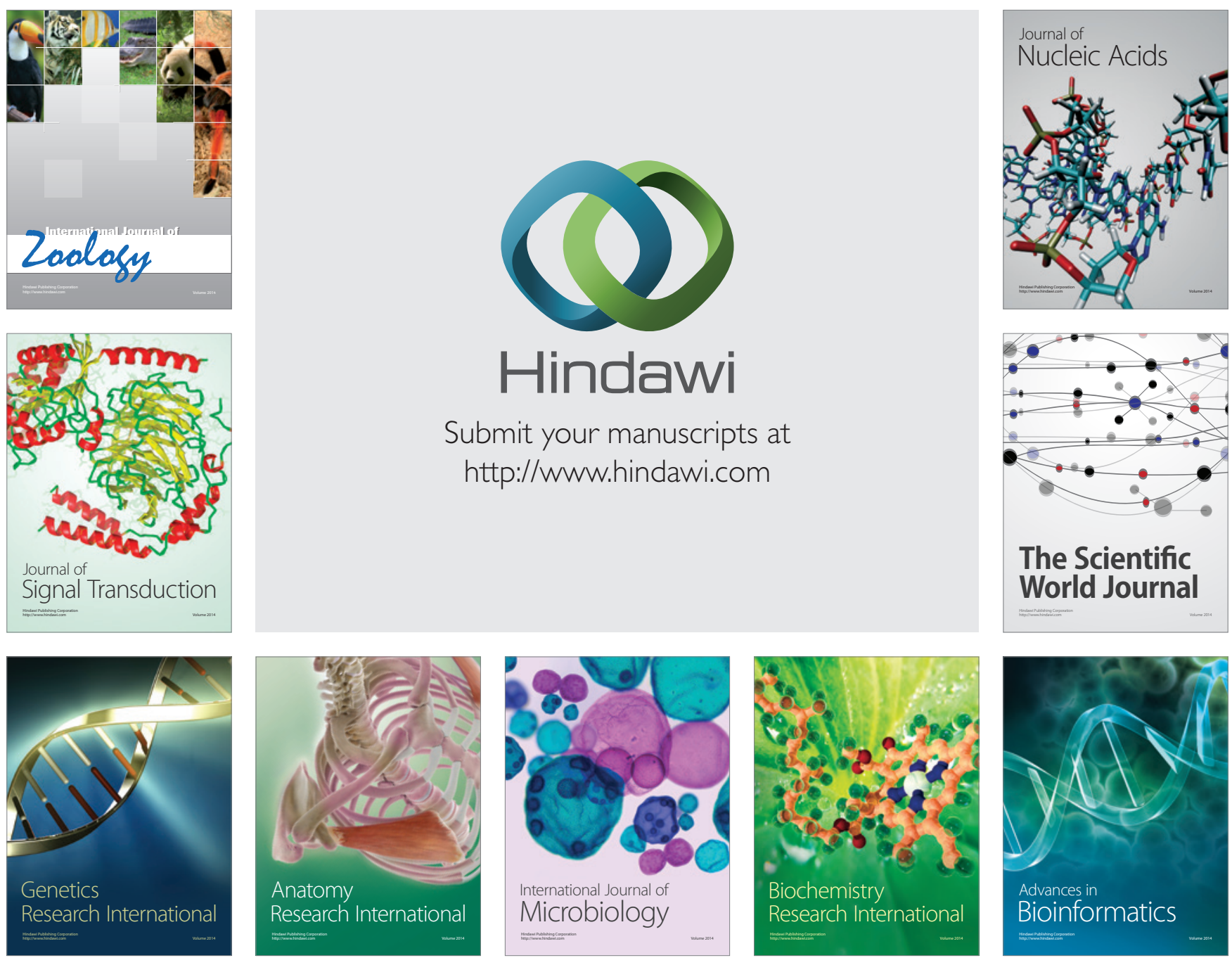

The Scientific World Journal
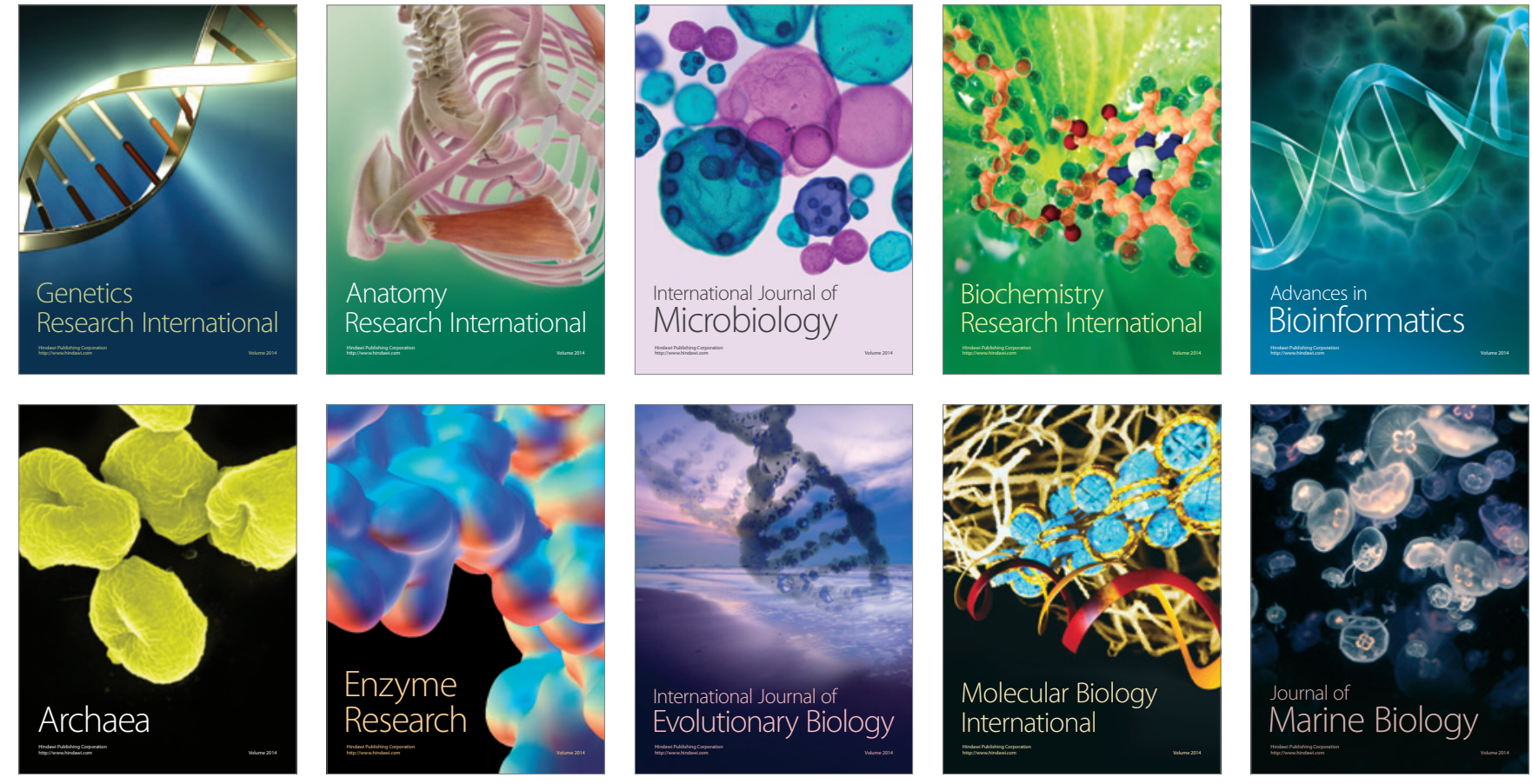